\title{
ІНФОРМАТИЗАЦІЯ ОХОРОНИ ЗДОРОВ'Я. ОСОБЛИВОСТІ АНАЛІЗУ ІНФОРМАЦІЇ В РЕАБІЛІТАЦІЙНОМУ ПРОЦЕСІ
}

\author{
О. П. Мінцер, Л. Ю. Бабінцева, О. А. Панченко \\ Національна медична академія післядипломної освіти імені П. А. Шупика
}

\begin{abstract}
У статті розглянуто питання концептуального узагальнення перспектив розвитку реабілітології у сучасній медицині на основі широкого використання інформаційних технологій. Представлено нову концепцію реабілітації. її основні відмінності складаються з трьох концептів: програму реабілітації слід розглядати починаючи зі стаціонарного періоду лікування пацієнта; моніторинг ризиків патологічного процесу є ланкою, що пов'язує та об'єднує стратегію лікарського нагляду та впливу на організм пацієнта; необхідність виділення, аналізу та стандартизації варіантів перебігу реабілітаційного періоду на основі принципів медичної онтології. У новій системі, що створюється, стає актуальним питання не етіології та патогенезу захворювання, а механізмів переходу організму від стану захворювання до стану здоров'я.
\end{abstract}

Ключові слова: реабілітація захворювання, реабілітологія, стандарти перебігу патологічного процесу, інформатизація охорони здоров'я, ризики несприятливого кінця, ризики ускладнень.

\section{ИНФОРМАТИЗАЦИЯ ЗДРАВООХРАНЕНИЯ. ОСОБЕННОСТИ АНАЛИЗА ИНФОРМАЦИИ В РЕАБИЛИТАЦИОННОМ ПРОЦЕССЕ}

\author{
О. П. Минцер, Л. Ю. Бабинцева, О. А. Панченко \\ Национальная медицинская академия последипломного образования \\ имени П. А. Шупика
}

\begin{abstract}
Инновационные процессы, происходящие в современном обществе, несомненно, коснулись и медицины. Обусловленные ими структурные и организационные преобразования в сфере здравоохранения требуют переосмысления многих постулатов, активизации резервов, и главное - привлечения самых современных технологий.

Особое внимание обращается на такое направление, как реабилитология и ее практическое воплощение реабилитация пациентов. Успешность решения проблем реабилитации определяется как наличием соответствующей материально-технической базы и достаточным уровнем подготовки медицинского персонала, так и методологическим уровнем медицины в целом. Поэтому постоянное видоизменение научно-практических задач реабилитации под влиянием процессов, возникающих в здравоохранении, неизбежно.

Цель работы - концептуальное обобщение перспектив развития реабилитологии в современной медицине на основе широкого применения информационных технологий.

Цель реабилитации должна заключаться не только в восстановлении работоспособности, но и в восстановлении достоинства человека, его социально-общественной самостоятельности. Такие суждения все чаще встречаются в новейших определениях понятия реабилитации.

Информационные технологии - это именно тот резерв, который позволяет повысить уровень реабилитационной помощи за счет внедрения новых организационных методов, новых средств и способов реабилитации. Знание современных тенденций информатизации реабилитологии - базис для определения дальнейших путей совершенствования этой отрасли. Условно выделяют три основных направления развития информационных технологий в реабилитологии: автоматизация диагностических и лечебных методик, информационная поддержка принятия врачебных решений, телереабилитация.

Авторами предложена новая концепция реабилитации. Ее основные отличия состоят в трех концептах: программу реабилитации следует рассматривать, начиная со стационарного периода лечения пациента; мониторинг рисков патологического процесса является связующим звеном, объединяющим стратегию врачебного наблюдения и воздействия на организм пациента; необходимость выделения, анализа и стандартизации вариантов течения реабилитационого периода на основе принципов медицинской онтологии. В создаваемой новой системе координат становится актуальным вопрос не этиологии и патогенеза болезни, а механизмов перехода организма от состояния болезни к состоянию здоровья.

В работе также предлагается оригинальное разделение реабилитационного периода на 4 этапа: клинический, санаторный, резидуальный, адаптационный.

Учитывая, что реабилитационные программы составляют индивидуально для каждого пациента с учетом общего состояния, особенностей течения заболевания, исходного уровня физического состояния, личности больного,
\end{abstract}


возраста, пола, профессии и т.п., их можно рассматривать как проект или предварительно распланированную систему мер.

Ключевые слова: реабилитация заболевания, реабилитология, стандарты течения патологического процесса, информатизация здравоохранения, риски неблагоприятного исхода, риски осложнений.

\title{
INFORMATIZATION OF HEALTH CARE. TNE ANALYSIS FEATURES OF INFORMATION ARE IN REHABILITATION PROCESS
}

\author{
O. P. Mintser, L.Yu. Babintseva, O. A. Panchenko \\ Shupyk National Medical Academy of Post-Graduate Education
}

Innovative processes in modern society, of course, touched and medicine. Caused by their structural and organizational changes in health care require a rethinking of many postulates, increased reserves, and most importantly - bringing the most advanced technology.

Particular attention is drawn to the area such as Rehabilitology and its practical implementation - Rehabilitation of patients. The success of the solutions of problems of rehabilitation is defined as the presence of the appropriate material and technical base and a sufficient level of training of medical personnel and methodological level of medicine in general. Therefore, a permanent modification of scientific and practical problems of rehabilitation under the influence of processes occurring in health care is inevitable.

Purpose - conceptual generalization prospects of Rehabilitation in modern medicine on the basis of extensive use of information technology. The goal of rehabilitation should be not only to restore health, but also in restoring the dignity of man, his social and social independence. Such judgments are more and more in the latest definitions of the concept of rehabilitation.

Information technology - this is the provision that allows you to raise the level of rehabilitation care through the introduction of new organizational methods, new ways and means of rehabilitation. Knowledge of current trends of information Rehabilitation, of course, is a basis for determining further ways to improve the industry. Conventionally, there are three main areas of information technology in Rehabilitation: the automation of diagnostic and therapeutic techniques of medical information to support decision- making, telerehabilitation.

The authors propose a new concept of rehabilitation. Its main differences are the three concepts: the rehabilitation program should be considered, ranging from inpatient treatment period, patient risk monitoring of the pathological process is the link that unites medical monitoring strategy and the impact on the patient, the need for analysis and standardization of variants of the rehabilitation period on the basis of principles of medical ontology. In the new coordinate system created becomes relevant issue is not the etiology and pathogenesis of the disease, and the mechanisms of the transition state of the body from illness to health.

The paper also proposed the original division of the rehabilitation period, into 4 stages: clinical, sanatorium, residual, adaptation.

Given that rehabilitation programs are individually designed for each patient, taking into account the general condition, the characteristics of the disease, the initial level of physical condition, the patient's personality, age, gender, occupation, etc., they can be viewed as a project or pre- plan the system of measures.

Key words: rehabilitation of the disease, standards of pathological processes, computerization of health, the risks of a negative treatment result, the complication risks of treatment.

Вступ. Інноваційні процеси, які відбуваються в сучасному суспільстві, безсумнівно, торкнулися й медичної галузі. Обумовлені ними структурні й організаційні перетворення в сфері охорони здоров'я потребують надання нового сенсу багатьом постулатам, активізації резервів, і головне, - залучення найсучасніших технологій.

Особлива увага звертається на такий напрям, як реабілітологія та ії практичне втілення - реабілітація пацієнтів. Успішність вирішення проблем реабілітації визначається як наявністю відповідної матеріально-технічної бази та достатнім рівнем підготовки медичного персоналу, так і методологічним рівнем медицини загалом. Тому постійне видозмінювання науково-практичних завдань реабілітації під впливом процесів, що виникають в охороні здоров'я, неминуче.

Найважливішого значення набуває обгрунтування методологічних принципів побудови концептуальних положень комплексної реабілітаційної допомоги, впровадження організаційно-функціональних принципів інформаційного забезпечення реабілітаційних закладів, сучасних технологій реабілітації, що забезпечують гарантії якості та необхідний обсяг реабілітаційної допомоги.

Мета роботи - концептуальне узагальнення перспектив розвитку реабілітології в сучасній медицині на основі широкого застосування інформаційних технологій.

Результати та їх обговорення. Всесвітня організація охорони здоров'я (ВОО3) застосовує таке виз- 
начення медичної реабілітації: «Медична реабілітація - активний процес, метою якого є досягнення повного відновлення функцій, що порушені внаслідок захворювання чи травми, або, якщо це нереально, оптимальної реалізації фізичного, психічного та соціального потенціалу інваліда, найбільшої інтеграції його в суспільство».

Проте не тільки термін, але й суть реабілітації в різних країнах розуміють по-різному. У одних основною їі метою вважають тільки відновлення здоров'я, в інших - відновлення працездатності. Якщо обмежитися тільки першим завданням, то важко відокремити його від лікування як такого. При цьому лікування, нехай навіть найуспішніше, в багатьох випадках не може повернути людині здатність працювати, а також соціальну та економічну незалежність. Мета реабілітації повинна полягати не тільки в відновленні працездатності, але й у відновленні гідності людини, іiї соціально-суспільної самостійності. Такі судження все частіше зустрічаються в новітніх визначеннях поняття реабілітації.

Звернемо увагу на неточне використання терміну реабілітація в конкретних напрямах медицини, а саме: хірургічна реабілітація, медикаментозна, акушерська, імунологічна тощо, оскільки завжди йдеться про реабілітацію пацієнта, а не його хвороби.

Інформаційні технології - це саме той резерв, котрий дозволяє підвищити рівень реабілітаційної допомоги за рахунок впровадження нових організаційних методів, нових засобів і способів реабілітації. Знання сучасних тенденцій інформатизації реабілітології базис для визначення подальших шляхів удосконалення цієї галузі. Очевидно, що інформаційні технології представляють найбільш динамічну складову глобальних змін у розвитку сучасного суспільства.

Умовно виділяють три головні напрямки розвитку інформаційних технологій у реабілітології: автоматизація діагностичних і лікувальних методик, інформаційна підтримка прийняття лікарських рішень, телереабілітація.

Інформатизація діагностичних і лікувальних методик припускає впровадження нових засобів діагностики та спрямованого зовнішнього впливу на організм (реабілітаційне обладнання, апаратно-програмні комплекси), що базуються на передових технологіях кібернетики, мікропроцесорної техніки, програмування тощо.

В усіх цих системах на першому місці знаходяться завдання точного дозування параметрів роботи, стабільного утримання їх заданих значень в умовах мінливих фізіологічних характеристик організму па- цієнта, впровадження «розумних технологій», що припускають змінення режимів роботи технологічних пристроїв із урахуванням аналізу трендів вимірюваних показників функціонування організму. Розвиток таких технологій потребує розгляду та вирішення багатьох практичних питань, на першому місці з яких - питання про необхідність широкого впровадження в клінічну практику апробованих засобів і методів інформаційно-технічного впливу, що відповідають таким вимогам, як безпека та простота їх використання, висока ефективність застосування, наступності тощо.

Інтерес практичної медицини до реабілітації обумовлений усвідомленням світовим медичним співтовариством недостатньої ефективності зусиль клінічної медицини в справі відновлення та компенсації втрачених у процесі хвороби фізіологічних функцій організму.

Звідси виникла необхідність при формуванні системного реабілітаційного підходу не тільки використовувати знання та методи різних наук про людину, але й творчо переробляти їх під цілі та завдання медичної реабілітації, перш за все з метою пошуку ефективних способів максимального відновлення фізіологічних, а потім соціальних і професійних функцій людини. Все це потребувало нових трактувань і визначень таких понять, як «здоров'я», «хвороба», «лікування», «реабілітація», «профілактика».

У новій системі, що створюється, стає актуальним питання не етіології та патогенезу захворювання, а механізмів переходу організму від стану захворювання до стану здоров'я. Це стимулює наукове вивчення феномену здоров'я, визначення його якісних і кількісних параметрів з урахуванням не тільки фізіологічних критеріїв, але й множини факторів середовища, з якими організм постійно та динамічно взаємодіє.

Дуже відоме формулювання ВООЗ про те, що «здоров'я - це стан психічного, фізичного та соціального благополуччя, а не тільки відсутність хвороб». Зазначимо, що всі три фактори, складові здоров'я індивіда, входять до поняттєвого та термінологічного апарату реабілітології.

Проте, на думку ряду вчених, таке визначення важко назвати науковим, оскільки в ньому взагалі відсутні будь-які вказівки на закономірності, що покладені в основу цього стану, немає кількісних характеристик здоров'я, відсутня логіка взаємодії людини та навко лишнього середовища.

Академік М. М. Амосов [3] писав, що поняття «здоров'я» - «це поки що якісне поняття меж норми, але 
визначення здоров'я тільки як комплексу нормальних показників явно недостатньо. Науковий підхід до поняття «здоров'я» повинен бути кількісним. «Кількість здоров'я» - ось що необхідно. Кількість здоров'я можливо визначити як суму «резервних потужностей» основних функціональних систем організму».

В ряді оглядових праць [4-6] наведені визначення терміну «здоров'я», в яких підкреслюються численні біологічні, фізіологічні, функціональні, психологічні, соціальні, етичні та інші компоненти або аспекти цього поняття. Частіше застосовуються такі терміни, як «відсутність хвороби», «нормальний стан», «динамічна рівновага організму та середовища», «здатність до повноцінного виконання біологічних і соціальних функцій», «повне фізичне, душевне та соціальне благополуччя, гармонійний розвиток організму, здатність пристосовуватися до динамічних умов навколишнього середовища» тощо.

Нові підходи до оцінювання та управління здоров' ям були запропоновані професорами О. П. Мінцером і Г. Л. Апанасенком. Зокрема, заслуговує на детальне обговорення таке визначення: «Під здоров'ям індивіда розуміється забезпечення квазістаціонарності фізіологічних, психологічних, біологічних, соціальних та інших характеристик функціонування людини при неекстремальних впливах навколишнього середовища». Особливістю цього визначення є внесення до відомої ВООЗівської дефініції індивідуального здоров'я понять навантажувальних характеристик і показників навколишнього середовища.

Запропоновані й інші визначення, зокрема «здоров'я - стан, що забезпечує виконання людиною своїх біологічних (виживання та репродукція) і соціальних функцій». Поняття «виживання (життєздатність)» та «репродукція» можуть бути ідентифіковані та кількісно охарактеризовані. Застосування запропонованої методики «виміру» здоров'я дозволяє визначити «безпечну зону», повернення до якої можна трактувати як «превентивну реабілітацію».

Трохи осторонь стоїть проблема інформаційного здоров'я. Ера інформаційного буму спричинила появу захворювань, в основі яких лежать причини інформаційного характеру. Вже давно відмічені окремі тенденції, які можна зв'язати з інформацією як фактором ризику: збільшення захворюваності населення на психічні розлади, неврози, хвороби системи кровообігу, зростання кількості самогубств, висока частка в структурі смертності інформаційно-залежних причин. У зв'язку з цим, пропонуємо розрізняти інформаційно обумовлене здоров'я. Інформаційне здоров'я - це та частина загального стану психічного, фізичного та соціального благополуччя, котра формується та залежить від інформації.

Розвиток системи ефективної медичної реабілітації з урахуванням сьогоднішнього рівня суспільного здоров'я без сумніву можна віднести до числа найважливіших медико -соціальних завдань сучасної охорони здоров'я. Ефективний розвиток системи медичної реабілітації потребує постійного розроблення іiі теоретичного фундаменту, в рамках котрого формуються науково обгрунтовані принципи побудови реабілітаційного процесу. Саме це й є головним завданням медичної реабілітології - прикладної медико-біологічної наукової дисципліни, що вивчає фундаментальні закономірності, механізми, процеси видужання, відновлення втрачених у процесі хвороби функцій організму, а також умови збереження та розвитку здоров'я [1].

Основна сутність і основні труднощі даного напряму полягають у тому, що динаміка показників функціонального стану організму в процесі реабілітації зовсім не обов'язково повинна повторювати динаміку переходу організму від стану «норма» в стан хвороби. Скоріше навпаки. Траєкторія руху організму до норми характеризується сполученням нових стаціонарних станів, новим набором ризиків і вибором управляючих впливів, що не є очевидними або достатньо обгрунтованими. Вкрай важливим елементом реабілітаційного періоду (на відміну від класичних уявлень про лікувальний процес) слід вважати необхідність моніторингу стану пацієнта з відмінними від прийнятих у медицині правовими співвідношеннями.

Саме тому реабілітація - поняття більш широке, ніж просто сукупність медичних методів і методик. Генеральною метою комплексної реабілітації як результату цілеспрямованих зусиль у медичному, педагогічному, соціальному й економічному аспектах $\epsilon$ відновлення та зміцнення здібностей людини найповніше брати участь у біологічному та соціальному житті. Але, не дивлячись на те, що реабілітація багатоплановий, багатокомпонентний процес, провідною в ньому є медична реабілітація, оскільки вона має за мету не тільки відновлення вихідного стану органів і систем організму, але й визначення межі функціональних можливостей людини в її подальшому житті. Іншими словами, успішність медичної реабілітації визначає можливість подальшої соціальної та професійної реабілітації. Медичну реабілітацію слід розглядати як систему заходів, що проводяться закладами охорони здоров' я, починаючи з поліклінічно- 
го та стаціонарного, а завершуючи санаторним етапом їі організації. Всі ці заходи направлені на одужання, компенсацію та відновлення порушених функцій, що формуються в результаті хвороби або травми, обмеження життєдіяльності та соціальної недостатності і пристосування хворого та інваліда до нових умов життя й трудової діяльності, що виникли в результаті хвороби [2].

Авторами запропонована нова концепція реабілітації. Її основні відмінності складаються з трьох концептів.

Перше положення включає постулат, що програма реабілітації пацієнта починається розглядатися вже на стаціонарному періоді лікування.

Відповідно реабілітацію хворого можна поділити на чотири етапи.

Вже на першому етапі - клінічному - необхідно провести межі між лікуванням та власне реабілітацією. 3 одного боку, лікувальні та реабілітаційні заходи проводяться одночасно, а інші цілі цих заходів відрізняються одна від одної. Лікування спрямоване на ліквідацію чи мінімальний прояв хвороби. Реабілітація спрямована на досягнення фізичної, трудової, соціальної адаптації людини.

Зазвичай після цього етапу реабілітації функціональні показники ураженої патологічним процесом системи в основному нормалізуються.

На другому етапі - санаторному - реабілітаційні заходи спрямовані на нормалізацію функцій уражених органів і систем, а також на відновлення та нормалізацію функцій інших органів і систем, ліквідацію відхилень, що залишилися. При цьому приділяється увага відновленню та розширенню фізичної активності хворого.

Третій період - резидуальний - здійснюється в санаторіях або в амбулаторних умовах. Він присвячений усуненню залишкових явищ патологічного процесу.

Нарешті, четвертий - адаптаційний або професійно-трудовий (для працюючих) - забезпечує максимально можливе одужання хворого з нормалізацією морфологічних і функціональних характеристик, стійку компенсацію втрачених під час хвороби функцій. Забезпечується фізична, психічна, соціальна повноцінність хворих, відновлення професійних навичок та звичайної працездатності.

Зрозуміло, що при хронічних захворюваннях, що призводять до інвалідизації хворих, завдання реабілітації полягають не тільки в досягненні стану компенсації функції органа, але й у підтримці цієї компенсації.

Друга відмінність запропонованої концепції полягає в тому, що ланкою, котра пов'язує та об'єднує стра- тегію лікарського нагляду та впливу на організм пацієнта, є моніторинг ризиків патологічного процесу. Саме управління ризиками, що модифікуються, $\epsilon$, на нашу думку, найважливішою характеристикою сучасного лікування та реабілітації пацієнтів.

Сьогодні розглядається цілий ряд можливих підходів до обгрунтування дій у реабілітації хворих: використання хіміотерапевтичних засобів (фармакотерапія), додаткове хірургічне лікування (операції такі, що зберігають, заміщають і коригують), психотерапія, використання фізичних чинників (кінезо- й ерготерапія, лікувальна фізкультура, фізіотерапія тощо).

Відмітимо, що в кожній клінічній дисципліні зазначені методи можуть бути застосовані як окремо, так і одночасно.

Отже, реабілітаційний напрям значно розширює уявлення про традиційне лікування, оскільки дозволяє об' єднати зусилля профілактичної, лікувальної та відновної медицини з діяльністю інших сфер суспільства.

Підкреслимо, що медична реабілітація є одним із етапів спеціалізованої медичної допомоги населенню, обов'язковим етапом медико-соціальних заходів на всіх напрямках лікарської допомоги.

Важливим аспектом є взаємозв'язок між реабілітаційними діями та застосуванням лікарських засобів (Л3). Абсолютно зрозумілим є намагання максимально зменшити обсяги ЛЗ під час реабілітаційного періоду лікування й, особливо, під час резидуального періоду.

Основного значення набувають дієта, режим, фізіотерапія, лікувальна фізкультура й інші методи лікування. Одужання без ЛЗ чинить більш сприятливий вплив. Проте, при хронічних захворюваннях, які призводять до інвалідизації хворих, відповідно до індивідуального плану спостереження проводяться періодичні курси медикаментозної й іншої терапії або призначається постійна терапія для забезпечення нормальної якості життя.

Природно, що навіть при сприятливому перебігу реабілітаційного періоду спостерігаються різні варіанти відновлення працездатності, які залежать від типу нервової діяльності пацієнта. При астенічній реакції на хворобу, що проявляється підвищеною стомлюваністю, млявістю та пасивністю, або депресивному типі реакції з почуттям тривоги, втрати бажання одужання, появи туги, розгубленості, або, нарешті, іпохондричному типі реакції із зануренням у хворобу та розвитком істеріоформних реакцій, - хворим необхідна психологічна реабілітація.

Нарешті, третій концепт, пов'язаний із виділенням, аналізом і стандартизацією варіантів перебігу реабі- 
літаційного періоду. Подібні процедури тісно пов'язані $з$ медичною онтологією. Ї̈̈ медичне значення пов'язано з тим, що вперше ставиться завдання обгрунтування стандартів саме перебігу патологічного процесу.

Отже, беручи до уваги, що реабілітаційні програми складають індивідуально для кожного хворого 3 урахуванням загального стану, особливостей перебігу хвороби, вихідного рівня фізичного стану, особистості хворого, віку, статі, професії тощо, їх можна розглядати як проект або систему заходів, котрі попередньо розплановані. Відповідно має місце розраховування можливих втручань у запланований хід подій із урахуванням внутрішніх і зовнішніх ризиків розвитку захворювання, визначенням прогностичних характеристик і мінімізації медикаментозного навантаження на організм.

\section{Література}

1. Медведев А. С. Основы медицинской реабилитологии / А. С. Медведев. - Минск : Беларус. навука, 2010. - 435 с.

2. Вальчук Э. А. Диспансеризация и медицинская реабилитация // Э. А. Вальчук // Вопросы организации и информатизации здравоохранения. - 2009. - №2. - С. 16-21.

3. Амосов Н. М. Моя система здоровья / Н. М. Амосов. К. : Здоров'я, 1997. - 56 с.

4. Концепція інформатизації охорони здоров'я України / Мінцер О. П., Вороненко Ю. В., Бабінцева Л. Ю. [та ін.] // Медична інформатика та інженерія. - 2012. - № 3. - С. 5-29.

5. Панченко О. А. Информационные технологии в практике врача / Панченко О. А., Банчук Н. В., Толстанов А. К. [и др.] - К. : КВИЦ, 2012. - 354 с.

6. Брехман И. И. Введение в валеологию - науку о здоровье / И. И. Брехман. - Л. : Наука, 1987. - 125 с.

7. Апанасенко Г. Л. Книга о здоровье / Г. Л. Апанасенко. К. : Медкнига, 2007. - 131 с.

8. Мінцер О. П. Інформатизація профілактичної медицини / О. П. Мінцер, Л. Ю. Бабінцева. - Информатизация реабилитационного процесса: матер. научно-практической конференции с международным участием, 7 ноября 2012 года, г Константиновка. - К.: КВИЦ, 2013. - С. 15-19.

9. Информатизация реабилитационно-диагностического процесса в современных медицинских учреждениях / [Панченко О. А., Пономаренко А. Н., Горбань А. Е.] // Реабили-
Висновки. 1. Запропоновано нову концепцію реабілітації. Її основні відмінності складаються з трьох концептів: програми реабілітації слід розглядати починаючи зі стаціонарного періоду лікування пацієнта; моніторинг ризиків патологічного процесу є ланкою, що пов'язує та об'єднує стратегію лікарського нагляду та впливу на організм пацієнта; необхідність виділення, аналізу та стандартизації варіантів перебігу реабілітаційного періоду на основі принципів медичної онтології.

2. У новій системі, що створюється, стає актуальним питання не етіології та патогенезу захворювання, а механізмів переходу організму від стану захворювання до стану здоров'я.

3. Пропонується поділ реабілітаційного періоду на чотири етапи: клінічний, санаторний, резидуальний, адаптаційний.

тация и абилитация человека. Клиническая и информационная проблематика : сб. науч. работ / под общ. ред. О. А. Панченко. - К.: КВИЦ, 2012. - С. 175-189.

10. Количественная оценка уровня здоровья / [Минцер О. П., Бутенко Л. Н., Салюта М. Е.] // От Алма-Аты к 2000 году - взгляд с половины пути. - Алма-Ата, 1988. - С. 275-278.

11. Козявкін В. І. Інформаційні технології в стандартизації та організації медичної реабілітації / В. І. Козявкін, О. О. Качмар // Український журнал телемедицини та медичної інформатики. - 2008. - Т. 6, № 2. - С. 211-213.

12. Владзимирский А. В. Телемедицина : монография / А. В. Владзимирский. - Донецк : Цифровая типография, 2011. -437 c.

13. Winters J. Telerehabilitation research: Emerging opportunities / J. Winters // Annual Review of Biomedical Engineering. - 2002. - № 4. - P. 287-320.

14. Telerehabilitation / Australian Physiotherapy Association Background Paper // Режим доступу: www.physiotherapy.asn.au/DocumentsFolder/Advocacy Background_Papers_Telerehabilitation.pdf.

15. Pramuka M. Telerehabilitation Technologies: Accessibility and Usability / M. Pramuka, L. vanRoosmalen// International Journal of Telerehabilitation. - 2009. - Vol. 1. - P. 85-98. 